\title{
Synthesis of Reconstituted Hemoglobins Containing Metalloporphyrin Derivatives and SOD Activity
}

\author{
Makoto Yuasa ${ }^{1,2 *}$, Aritomo YAMAguchi ${ }^{1}$, Satoshi Mikami ${ }^{1}$, \\ Uichi Midorikawa ${ }^{1}$, Yoshihiro KawaKami ${ }^{3}$ and Shoji Nagaoka ${ }^{3}$ \\ ${ }^{1}$ Department of Pure and Applied Chemistry, Faculty of Science and Technology, Tokyo University of Science \\ (2641 Yamazaki, Noda 278-8510, JAPAN) \\ ${ }^{2}$ Institute of Colloid and Interface Science, Tokyo University of Science \\ (1-3 Kagurazaka, Shinjyuku, Tokyo 162-8601, JAPAN) \\ ${ }^{3}$ Department of Applied Chemistry, Tokyo Metropolitan University \\ (1-1 Minami-osawa, Hachioji, Tokyo 192-0397, JAPAN)
}

Edited by H. Shimasaki, Teikyo Univ., and accepted November 14, 2002 (received for review October 8, 2002)

\begin{abstract}
To establish a method for the effective mimicking superoxide dismutase (SOD) which accerelate scavenging of the superoxide anion radical $\left(\mathrm{O}_{2}^{-{ }^{-}}\right)$, reconstituted hemoglobins each possessing the apoprotein of hemoglobins as carriers and various metalloporphyrins as active sites were synthesized and their SOD activity was determined in each case. The hemoglobins containing iron- and manganese-protoporphyrin IX (2-4) had no significant SOD activity but did so when containing cationic iron- and manganese-porphyrins (5-7). Minimum $\mathrm{IC}_{50}$ as indicator of SOD activity was 1.8. $\mathrm{t}_{\mathrm{d}}$ as indicator of hydrogen peroxide resistance was always nearly 10 times that cationic metalloporphyrins as an SOD mimic. The reconstituted hemoglobins with cationic metalloporphyrins (5-7) are shown by the present results to be potentially capable of functioning as SOD mimics.
\end{abstract}

Key words: superoxide anion radical $\left(\mathrm{O}_{2}{ }^{-\cdot}\right)$, superoxide dismutase (SOD) activity, SOD mimic, reconstituted hemoglobin, cationic metalloporphyrin

\section{1 緒言}

生体に打いてスーパーオキシドアニオンラジカル $\left(\mathrm{O}_{2}{ }^{-*}\right)$ のような活性酸素種は生命機構を支える不可欠 な因子として機能して打り，また，過剩な活性酸素種 の生成に対してはスーパーオキシドジスムターゼ (SOD) , グルタチオンペルオキシダーゼ，カタラーゼ 等のラジカル消去系酵素を備えることによりバランス を保っている。しかしながら, 生体内で活性酸素種の 生成と消去の恒常性が崩れて酸化ストレス状態になる と, 大量の活性酸素種が生成されて強いラジカル毒性 が生じ, 引いては, 炎症疾患, 神経疾患, 動脈硬化,
癌，糖尿病，虚血再灌流障害，加齢促進等の多くの病 態に陥るとも考えられている $(1,2)$ 。このため, 生体 内の過剩な活性酸素種の消去や代謝を促進する検討が 必要となる。最近, このような検討の一つとして, $\mathrm{O}_{2}{ }^{-*}$ の消去・代謝反応 [(1) 式] を促進する SOD モデ ル化合物やSOD 様抗酸化剂の検討が行われている (2-12)。特に, 生体内に存在するへムタンパク質の活 性部位（へム）である金属ポルフィリンの低分子系や 高分子系の化合物による検討が行われている $(3-5,10$, 12)。本報では，生体適合性を踏まえた新規な SOD モ デル化合物の検討として，へモグロビン（Fig. 1, 1）の アポタンパク質（4個のグロビン鎖ユニットの集合体）

*Correspondence to: Makoto YUASA, Department of Pure and Applied Chemistry, Faculty of Science and Technology, Tokyo University of Science, 2641 Yamazaki, Noda 278-8510, JAPAN

E-mail: yuasa@ci.noda.sut.ac.jp 
を担体とし，その活性部位を SOD 活性を有する金属ポ ルフィリン誘導体に置き換えた再構成へモグロビン

（Fig. 1, 2～7）を各種合成し，それらについて SOD 活性等の機能評価を行った。

$$
2 \mathrm{O}_{2}^{-\cdot}+2 \mathrm{H}^{+} \rightarrow \mathrm{O}_{2}+\mathrm{H}_{2} \mathrm{O}_{2}
$$

\section{2 実験}

\section{$2 \cdot 1$ 試料}

活性部位となる鉄 $\{5,10,15,20$-テトラキス (2-N-メチ ルピリジル)ポルフィリン $\}(\mathrm{FeT} 2 \mathrm{MPyP})$ ，マンガン $\{5$, 10, 15, 20-テトラキス (2-N-メチルピリジル) ポルフィリ ン $\}$ (MnT2MPyP) 扎よびマンガン $\{5,10,15,20$-テトラ
キス (4-N-メチルピリジル) ポルフィリン\} (MnT4MPyP) は，既報（13-17）を参考に合成した。鉄プロトポル フィリンIX (FePPIX) およびマンガンプロトポルフィ リンIX (MnPPIX) は，市販品特級のプロトポルフィリ ンIX（和光純薬工業）に, 各々, 鉄イオンおよびマン ガンイオンを導入して合成した $(16,17)$ 。なお，これ らの化合物の構造確認は, ${ }^{1}$ H-NMR, FAB-Mass, UVvis 等より行った。

ヘモグロビン（1）として成人ヒトへモグロビン [へ モグロビン $\mathrm{A}$ ，和光純薬工業］を使用した。

他の試薬は市販品特級打よび純水はイオン交換水を 使用した。

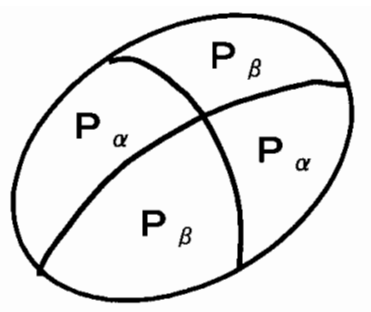

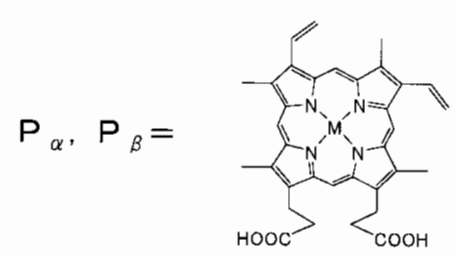

MPPDX

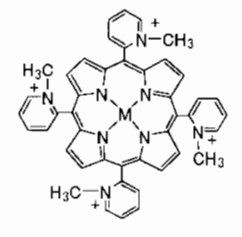

MT2MPyP

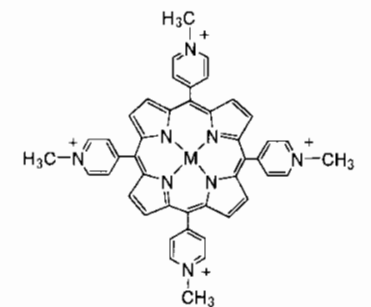

MT4MPyP

\begin{tabular}{c|c|c}
\hline Abbreviation & $\mathrm{P}_{\alpha}$ & $\mathrm{P}_{\beta}$ \\
\hline$\underline{1}$ & FePPIX & FePPIX \\
\hline$\underline{2}$ & FePPIX & MnPPIX \\
\hline$\underline{3}$ & MnPPIX & FePPIX \\
\hline$\underline{4}$ & MnPPIX & MnPPIX \\
\hline$\underline{5}$ & FeT2MPyP & FeT2MPyP \\
\hline$\underline{6}$ & MnT2MPyP & MnT2MPyP \\
\hline$\underline{7}$ & MnT4MPyP & MnT4MPyP
\end{tabular}

Fig. 1 Hemoglobin (1) and Various Reconstituted Hemoglobins (2 to 7). $\mathrm{P}_{\alpha}$ and $\mathrm{P}_{\beta}$ are active sites of $\alpha$ - and $\beta$-subunits, respectively. MPPIX, MT2MPyP and MT4MPyP are metalloprotoporphyrin IX, metallo $\{5,10,15,20$-tetrakis (2$\mathrm{N}$-methylpyridylporphyrin) $\}$ and metallo $\{5,10,15,20$-tetrakis (4-Nmethylpyridylporphyrin) $\}$, respectively $\{\mathrm{M}$ are iron $(\mathrm{Fe})$ and manganese $(\mathrm{Mn})\} . \mathbf{1}$ is hemoglobin (referred sample). 


\section{$2 \cdot 2$ 再構成へモグロビンの合成}

Fig. 1 に示した 6 種類の再構成へモグロビン（2 7）は既報（18一25）を参考に合成した（Fig. 2)。

\section{$2 \cdot 2 \cdot 1 \quad 2$ 打よび 3 の合成}

(1) 2 の合成

（I-(1)）常圧， $5{ }^{\circ} \mathrm{C}$ 以下の条件において，酸素化したへ モグロビン [1g, UV-vis : 吸収極大 $\left(\lambda_{\max }\right)$ 413, 540, 576 $\mathrm{nm}$ ）の $10 \%$ 水溶液 $(10 \mathrm{ml})$ に $20 \mathrm{mM}$ リン酸二水素ナ トリウム水溶液 $(1 \mathrm{ml})$ 扎よび飽和塩化ナトリウム水 溶液 $(0.15 \mathrm{ml})$ を加えた後, p-クロロ水銀安息香酸ナ トリウム（50 mg）が飽和した塩化ナトリウム水溶液を 加えた。さらに，この水溶液に $1 \mathrm{M}$ 酢酸水溶液を加え て pH 5.8 に調整し, 常圧, $5^{\circ} \mathrm{C}$ 以下で一晚放置した。次 に, この水溶液を透析 [Viskase Sales Corp (VSC), Seamless Cellulose Tubing（SCT） UC8-32-25 / pH 7.4, $50 \mathrm{mM}$ リン酸緩衝水溶液／12 時間］し，変性物を弓過 して $\alpha$ - および $\beta$-サブユニットを含む水溶液を得た。 $\alpha$ 打よび $\beta$-サブユニットを等電点電気泳動法（BIO-RAD, 分取用電気泳動装置ロトフォア）により単離, 精製し た。具体的には，上記の $\alpha$ - および $\beta$-サブユニットを含 む水溶液に $\mathrm{pH}$ 勾配（pH 5.8 ～8.2） を形成する両性担 体の水溶液 $(2 \mathrm{ml})$ を加え, さらに, 純水を加えて全 量を $58 \mathrm{ml}$ とした。この水溶液を $1200 \mathrm{~W} て ゙ ~ 4$ 時間，電 気泳動した。均一であった水溶液は二つの領域に分か れ， $\alpha$-サブユニット（pH $7.2 \sim 7.3 ）$ および $\beta$-サブユ

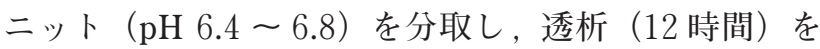

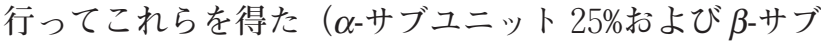
ユニット $15 \%)$ 。

(I-2) $\beta$-サブユニットを含む $\mathrm{pH} 7.0 \sim 7.2,50 \mathrm{mM}$ リ ン酸緩衝水溶液に $1 \mathrm{~N}$ 塩酸を加えて $\mathrm{pH}$ を $2.3 \sim 2.5$ に 調整した後，2-ブタノンを加えて分液漏斗で抽出した。 水層（下層）にアポ化した $\beta$-サブユニットおよび 2 -ブ タノン層（上層）に FePPIX を得た。アポ化 $\beta$-サブユ ニットの確認はUV-vis を用い, 水層に FePPIX 由来の 吸収ピークがなくなるまで操作を繰り返した。次に， このアポ化 $\beta$-サブユニットを含むリン酸緩衝水溶液を 透析（VSC, SCTUC8-32-25 / pH 7.2, 50 mM リン酸緩衝 水溶液／ 12 時間）してアポ化 $\beta$-サブユニットを得た $(90 \%)$ 。

(I-3)） アポ化 $\beta$-サブユニットを含む $\mathrm{pH} 7.0$ ～7.2, 50 $\mathrm{mM}$ リン酸緩衝水溶液に 1.2 倍 $\mathrm{mol}$ 量の MnPPIX を含 む $1 \mathrm{~N}$ 水酸化ナトリウム水溶液を混合し，放置した（室 温,数分間)。この水溶液をろ過し，さらに， GPC (Sephadex G-25 $/ 3 \mathrm{~cm} \phi \times 50 \mathrm{~cm} / \mathrm{pH} 7.0 \sim 7.2,50$ $\mathrm{mM}$ リン酸緩衝水溶液）により精製して MnPPIX を活 性部位とする $\beta$-サブユニット（MnPPIX 化 $\beta$-サブユ ニット）を得た（90\%, UV-vis： $\lambda_{\max } 467,552 \mathrm{~nm}$ )。

（I-(4)）MnPPIX 化 $\beta$-サブユニットを含む水溶液に2メルカプトエタノールを過剩に加え，放置した（室温， 30 分間)。この混合溶液を GPC (Sephadex G-25 / 3 $\mathrm{cm} \phi \times 50 \mathrm{~cm} / \mathrm{pH} 7.0 \sim 7.2,50 \mathrm{mM}$ リン酸緩衝水溶 液）に通した。上記 I-(1)で得られた $\alpha$-サブユニット

( I )
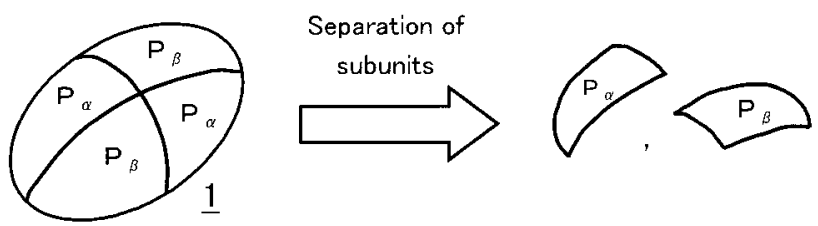

Productions of apo-proteins
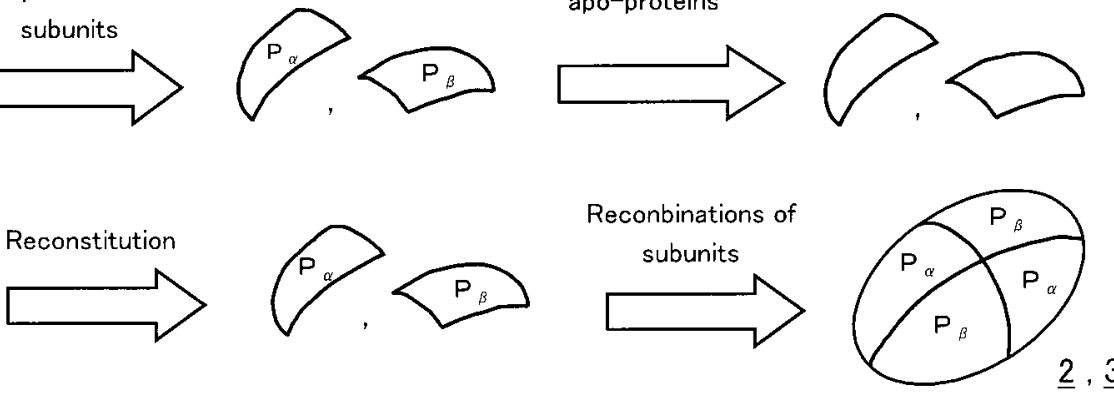

(II)
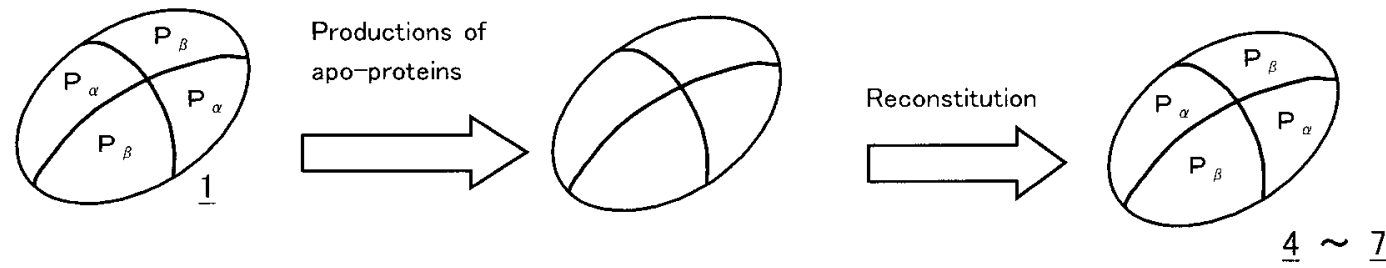

Fig. 2 Schematic Diagrams of Syntheses of Various Reconstituted Hemoglobins (2 to 7). Compound 1 and compounds $\mathbf{2}$ to $\mathbf{7}$ are hemoglobin and reconstituted hemoglobin, respectively, as shown in Fig. 1. 
（FePPIX 含有）についても同様の処理を行った。処理 した MnPPIX 化 $\beta$-サブユニットを含むリン酸緩衝水溶 液 $(\mathrm{pH} 7.0 \sim 7.2,50 \mathrm{mM})$ と同様に処理した $\beta$-サブユ ニットを含むリン酸緩衝水溶液（この場合, 常に $\beta$-サ ブユニットは $\alpha$-サブユニットに対して少過剩量添加） を混合し，放置した（8 時間）。この後，この水溶液を イオン交換クロマトグラフィー（陰イオン交換樹脂 DEAE-セルロース $/ 3 \mathrm{~cm} \phi \times 30 \mathrm{~cm} / \mathrm{pH} 7.0$ リン酸緩 衝水溶液）にかけて分取し，さらに，透析（12 時間） して目的物質である 2 を得た [75\%, 全収率 $9.1 \%$, UV-vis (還元体)： $\left.\lambda_{\max } 433,555,587 \mathrm{~nm}\right]$ 。

(2) 3 の合成

(1) の I-(1)で得られた $\alpha$-サブユニットについて ，(1) の I-(2)と同様に行ってアポ化 $\alpha$-サブユニット（92\%） を, さらに，(1）の I-(3)と同様に行って MnPPIX 化 $\alpha$ サブユニットを得た (90\%, UV-vis ： $\left.\lambda_{\max } 467,552 \mathrm{~nm}\right)$ 。 次に，(1) の I-(4)と同様に行い，目的物質である 3 を 得た [全収率 15\%, UV-vis（還元体）： $\lambda_{\text {max }} 433,555,588$ $\mathrm{nm}$ 。

\section{$2 \cdot 2 \cdot 2 \quad \mathbf{4} \sim \mathbf{7}$ の合成}

(1) 4 の合成

（II-(1)）へモグロビン（1g）を含む $\mathrm{pH} 7.0$ ～7.2, 50 $\mathrm{mM}$ リン酸緩衝水溶液に $1 \mathrm{~N}$ 塩酸を加えて $\mathrm{pH}$ を 2.3 2.5 に調整した後，2-ブタノンを加えて分液漏斗で抽出 した。水層（下層）にアポ化したへモグロビンおよび 2-ブタノン層（上層）にF F PPIX を得た。アポ化へモグ ロビンの確認はUV-vis を用い，水層に FePPIX 由来の 吸収ピークがなくなるまで操作を繰り返した。次に， このアポ化へモグロビンを含むリン酸緩衝水溶液を透 析（VSC, SCTUC8-32-25 / pH 7.2, 50 mM リン酸緩衝水 溶液／12 時間）てアポ化へモグロビンを得た（90\%)。

(II-(2)）アポ化へモグロビンを含む pH $7.0 〜 7.2,50$ $\mathrm{mM}$ リン酸緩衝水溶液に 4.2 倍モル量の MnPPIX を含 む $1 \mathrm{~N}$ 水酸化ナトリウム水溶液を混合し, 放置した（室 温, 数分間)。この水溶液をろ過し, さらに, GPC (Sephadex G-25 / $3 \mathrm{~cm} \phi \times 50 \mathrm{~cm} / \mathrm{pH} 7.0 \sim 7.2,50$ $\mathrm{mM}$ リン酸緩衝水溶液）により精製して目的物質であ る 4 を得た（90\%，全収率 81\%, UV-vis ： $\lambda_{\max } 467,552$ $\mathrm{nm})$ 。

(2) 5 の合成

(1) の II-(1)で得られたアポ化へモグロビン含む $\mathrm{pH}$ 7.0 ～7.2, $50 \mathrm{mM}$ リン酸緩衝水溶液に 4.2 倍モル量の FeT2MPyP を含む水溶液を混合し，超音波照射（15 W）下で放置した（室温，12 時間）。この水溶液を GPC (Sephadex G-25 $/ 3 \mathrm{~cm} \phi \times 50 \mathrm{~cm} / \mathrm{pH} 7.0 \sim 7.2$, $50 \mathrm{mM}$ リン酸緩衝水溶液) で精製し, 目的物質である 5 を得た（全収率 81\%, UV-vis： $\lambda_{\max } 396,515 \mathrm{~nm}$ )。

(3) 6 の合成
(1) のII-(1)で得られたアポ化へモグロビンと MnT2MPyP を用いて（2）と同様な操作を行い，目的 物質である 6 を得た（全収率 $81 \%$, UV-vis : $\lambda_{\max } 456$, $558 \mathrm{~nm})$ 。

(4) 7 の合成

(1) のII-1)で得られたアポ化へモグロビンと MnT4MPyP を用いて（2）と同様な操作を行い，目的 物質である 7 を得た（全収率 79\%, UV-vis ： $\lambda \max _{\max } 453$, $558 \mathrm{~nm})$ 。

\section{$2 \cdot 3$ 測定}

\section{$2 \cdot 3 \cdot 1$ SOD 活性評価}

各種再構成へモグロビン $(\mathbf{2} \sim \mathbf{7})$ の SOD 活性をチ トクローム c 法 $(26,27)$ により評価した。金属ポル フィリン濃度で 0 〜 $300 \mu \mathrm{M}$ の再構成へモグロビン水溶 液 $(\mathrm{A}$ 溶液）を 5 水準以上調製した。次に， $0.3 \mathrm{mM}$ キ サンチン（Aldrich/Sigma）水溶液， $60 \mu \mathrm{M}$ チトクロー 厶 $\mathrm{c}$ (Aldrich/Sigma) 水溶液打よ $\mathrm{pH} 7.8,30 \mathrm{mM}$ リン 酸緩衝水溶液を各 $20 \mathrm{ml}$ 加え, さらに, 純水 $24 \mathrm{ml}$ を加 えて混合溶液（B 溶液）を得た。この B 溶液 $2.1 \mathrm{ml}$ に $\mathrm{A}$ 溶液 $0.3 \mathrm{ml}$ と純水 $0.2 \mathrm{ml}$ を加えて放置 $\left(25^{\circ} \mathrm{C}, 10\right.$ 分) した。放置後の混合溶液に $7 \mu \mathrm{g} / \mathrm{ml}$ カタラーゼ (Aldrich/Sigma) 水溶液 $0.1 \mathrm{ml}, 25 \mathrm{U} / \mathrm{ml}$ キサンチンオ キシダーゼ（XOD, Aldrich/Sigma）水溶液 $0.3 \mathrm{ml}$ をす ばやく混合して $550 \mathrm{~nm}$ における UV-vis の経時測定を 行った（島津製作所, 分光光度計 UV-2100)。最終的な 試験溶液の各成分の濃度は，再構成へモグロビン 0 $30 \mu \mathrm{M}$ ，キサンチン $0.05 \mathrm{mM}$, XOD $2.5 \mathrm{U} / \mathrm{ml}$, チトク ローム c $10 \mu \mathrm{M}$ およびカタラーゼ $0.23 \mu \mathrm{g} / \mathrm{ml}$ である。 なお，参照としてへモグロビン（1）についても同様に SOD 活性評価を行った。

$2 \cdot 3 \cdot 2$ 非 XOD 活性阻害性評価

SOD 活性評価に伴い，再構成へモグロビン活性部位 の非 XOD 活性阻害性について既報（28－30）を参考に 検討した。0.56 mM キサンチン水溶液 $(2.7 \mathrm{ml})$ と 25 $\mathrm{U} / \mathrm{ml}$ XOD 水溶液 $(0.3 \mathrm{ml})$ をすばやく混合し，尿酸に 基づく $\lambda_{\max } 290 \mathrm{~nm}$ における UV-vis の経時測定を行っ た（島津製作所，分光光度計 UV-2100）。さらに，活性 部位である $0.3 \mathrm{mM}$ カチオン性金属ポルフィリン溶液 $(30 \mu \mathrm{l})$ を微量後添加し, 上記と同様の測定を継続して 行った。

\section{$2 \cdot 3 \cdot 3 \quad \mathrm{O}_{2}{ }^{-}$消去反応性評価}

SOD 活性評価に伴い，再構成へモグロビン活性部位 の $\mathrm{O}_{2}{ }^{-\cdot}$ 消去反応性について既報（28-30）を参考に検 討した。2 $22 \mathrm{nM}$ 西洋ワサビペルオキシダーゼ (HRP) および $2.0 \mu \mathrm{M}$ スコポレチンを含んむリン酸緩衝水溶液 (1 ml) と $0.1 \sim 2.0 \mu \mathrm{M}$ の過酸化水素 $\left(\mathrm{H}_{2} \mathrm{O}_{2}\right)$ 水溶液 （1 ml）を混合した溶液のけい光スペクトルを測定した 
（島津製作所，分光蛍光光度計 RF-5300PC，励起波長 $366 \mathrm{~nm}$ ，䖝光波長 $460 \mathrm{~nm}$ )。なお，ブランクとして $\mathrm{H}_{2} \mathrm{O}_{2}$ を含まない溶液も測定し，その蛍光強度を $100 \%$ とした。

\section{$2 \cdot 3 \cdot 4 \quad \mathrm{H}_{2} \mathrm{O}_{2}$ に対する安定性評価}

再構成へモグロビンの $\mathrm{H}_{2} \mathrm{O}_{2}$ に対する安定性を既報 （31－33）を参考に評価した。金属ポルフィリン濃度で $100 \mu \mathrm{M}$ の再構成へモグロビン水溶液（試料溶液）に30 $\mathrm{mM} \mathrm{H}_{2} \mathrm{O}_{2}$ 水溶液を添加（金属ポルフィリン錯体に対し て 300 倍 $\mathrm{mol}$ の $\mathrm{H}_{2} \mathrm{O}_{2}$ 量）し，金属ポルフィリン錯体の $\lambda_{\text {max }}\left(400 \mathrm{~nm}\right.$ 付近） および $\mathrm{H}_{2} \mathrm{O}_{2}$ の $\lambda_{\text {max }}(240 \mathrm{~nm})$ にお ける UV-vis の経時測定を行った（島津製作所，分光光 度計 UV-2100)。なお，参照として低分子系 SOD モデ ル化合物であるカチオン性金属ポルフィリン (FeT2MPyP, MnT2MPyP および MnT4MPyP) につい ても同様に評価した。

\section{3 結果および考察}

\section{$3 \cdot 1$ 再構成へモグロビンの SOD 活性}

再構成へモグロビン $(\mathbf{2} \sim \mathbf{7})$ の SOD 活性, すなわ ち, $\mathrm{O}_{2}{ }^{-}$消去活性をチトクローム $\mathrm{c}$ 法 $(26,27)$ より検 討した。一般に, $\mathrm{O}_{2}{ }^{-*}[(2)$ 式の反応で生成]により フェリチトクローム c [Cyt.c $\left.\left(\mathrm{Fe}^{3+}\right)\right]$ がフェロチトク ローム c [Cyt.c- $\left.\left(\mathrm{Fe}^{2+}\right), \lambda_{\max } 550 \mathrm{~nm}\right]$ に還元される [(3) 式] が，SOD や SOD 活性を有する物質の存在に より（1）式が促進され，この還元が阻害される。この 阻害の度合を分光学的手法 (フェェロチトクローム c 生成に起因する $550 \mathrm{~nm}$ 付近での吸光度測定）により求 める方法である $(26,27)$ 。

一例として, Fig. 3 に各種濃度の 7 を添加したチトク

$$
\begin{aligned}
& \text { Xanthine }+\mathrm{O}_{2} \stackrel{\mathrm{XOD}}{\longrightarrow} \text { Uric acid }+\mathrm{O}_{2}^{-\cdot} \\
& \text { Cyt.c }\left(\mathrm{Fe}^{3+}\right)+\mathrm{O}_{2}^{-\cdot} \longrightarrow \text { Cyt.c }\left(\mathrm{Fe}^{2+}\right)+\mathrm{O}_{2}
\end{aligned}
$$

[XOD : xanthine oxidase, Cyt.c $\left(\mathrm{Fe}^{3+}\right)$ : ferric-cytochrome c, Cyt.c $\left(\mathrm{Fe}^{2+}\right)$ : ferro-cytochrome c]

ローム c の還元の初期の経時変化を示す。 7 を添加して いない系（ブランク，Fig. 3 の a) に比べ， 7 を添加し た系（Fig. 3 の b e) に打ける傾きは低下し，添加濃 度の増大と共にその度合も増している。また, 本反応 に扔いて Cyt.c $\left(\mathrm{Fe}^{2+}\right)\left(\lambda_{\max } 550 \mathrm{~nm}\right)$ の形成も UV-vis よ り確認した。なお，他の再構成へムグロビン添加系に おいても同傾向の結果となった。次に, Fig. 3 の関係

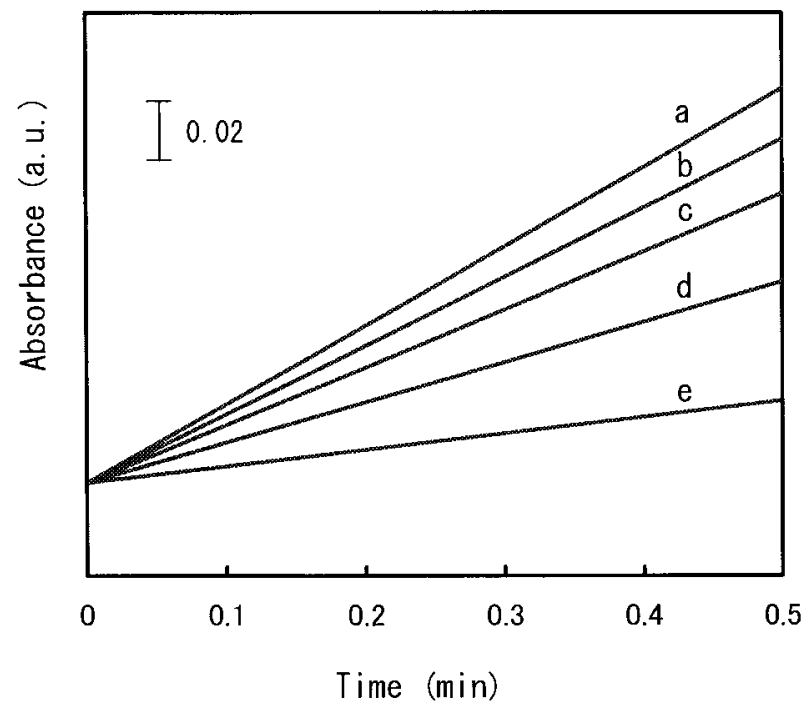

Fig. 3 Absorbance Versus Time Relations at $550 \mathrm{~nm}$ and at Initial Period Based on the Formation of Ferro-Cytchrome c in Phosphate Buffer Solution Containing $0.05 \mathrm{mM}$ Xanthine, $2.5 \mathrm{U} / \mathrm{ml} \mathrm{XOD}$, $10 \mu \mathrm{M}$ Cytchrome $\mathrm{c}$ and $0.23 \mu \mathrm{g} / \mathrm{ml}$ Catalase without (Blank) and with $\mathbf{7}$ at Room Temperature. MnT4MPyP conc. $(\mu \mathrm{M})$ of $\mathbf{7}$, a: $0, \mathrm{~b}: 1.0, \mathrm{c}: 2.5$, d: 4.0 and e: 5.5 .

より 7 の無添加系抢よび添加系での Cyt.c $\left(\mathrm{Fe}^{2+}\right)$ の生 成速度 $\left(\mathrm{v}_{\mathrm{i}}\right.$ および $\mathrm{v}_{\mathrm{o}}$ ) を求めた。さらに，(4) 式を用 いて阻害率を算出した。他の再構成へムグロビン系に ついても同様に行った。各種再構成へムグロビン添加 系に扎ける阻害率と金属ポルフィリン濃度の関係の一 例を Fig. 4 に示す。これより，阻害率 50\%に打ける金 属ポルフィリン濃度 $\left(\mathrm{IC}_{50}\right)$ を求め, これを $\mathrm{SOD}$ 活性 の指標とした。各種再構成へモグロビンの $\mathrm{IC}_{50}$ を Table 1 にまとて示す。なお，参照として再構成してい ないへモグロビン $(\mathbf{1})$, 活性部位のみである低分子系の カチオン性金属ポルフィリン (FeT4MPyP, MnT2MPyP および MnT4MPyP)，SOD 等の $\mathrm{IC}_{50}$ も合わせて示す。

サブユニットの影響を考慮した再構成へモグロビン (2 および 3) や活性部位の金属イオンの影響を考慮し た再構成へモグロビン（4）の $\mathrm{IC}_{50}$ は，参照として用い た再構成していないへモグロビン（1）のそれと差がな く, 単純なサブユニット, 金属イオン種等の制御のみ では効果的な SOD モデル化合物は得られなかった。次 に，活性部位に $\mathrm{O}_{2}{ }^{-}$(アニオン性）を導き易い反対電 荷（カチオン性）を活性部位周囲に構築したカチオン 性金属ポルフィリンを含む再構成へモグロビン $(\mathbf{5 , 6}$ および 7）では，それらの $\mathrm{IC}_{50}$ は大きく低下している。 特に, $\mathrm{Fe}$ イオンよりも $\mathrm{Mn}$ イオンの系 $\left(\mathrm{IC}_{50}\right.$ で $5>6$ ) が，打よび，カチオン性基の 4 位置換よりも 2 位置換 


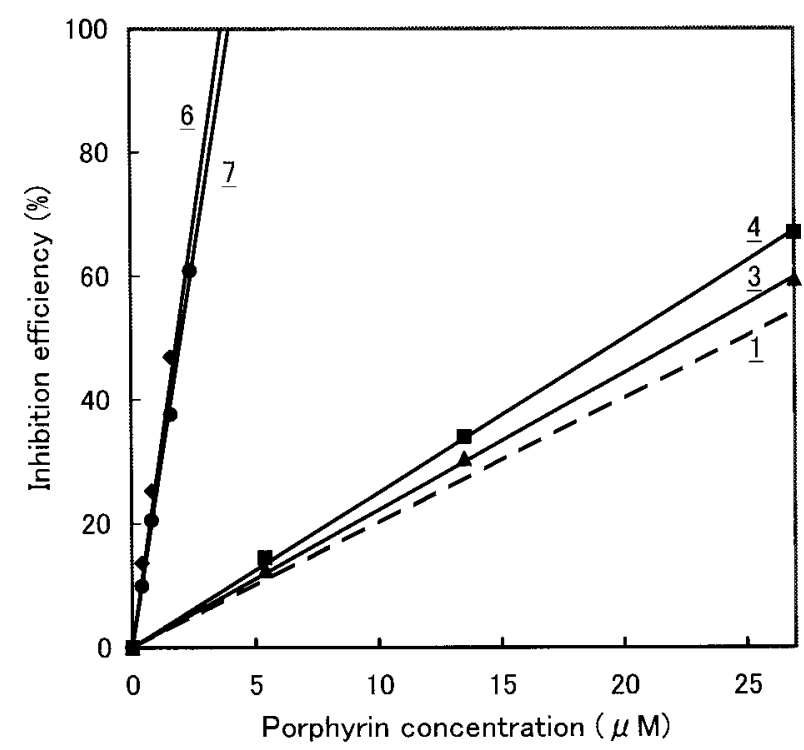

Fig. 4 Relationship between Inhibition Efficiency (\%) and Metallo-Porphyrin Concentration $(\mu \mathrm{M})$ of Reconstituted Hemoglobin. ----- ; 1, ; $\mathbf{3}$, $\mathbf{\Delta} ; \mathbf{4}, \mathbf{\square} ; \mathbf{6}$ and $>\mathbf{7}$.

Table $1 \mathrm{IC}_{50}$ Values of Various Reconstituted Hemoglobins by Cytchrome c Method.

\begin{tabular}{|c|c|c|}
\hline Compounds & $\mathrm{IC}_{50}(\mu \mathrm{M})$ & Refs. \\
\hline \multicolumn{3}{|l|}{ Reconstiuted hemoglobin } \\
\hline $2\left[\mathrm{P}_{\alpha}:\right.$ FePPIX, $\mathrm{P}_{\beta}:$ MnPPIX $]$ & 23 & This work \\
\hline $3\left[\mathrm{P}_{\alpha}: \mathrm{MnPPIX}, \mathrm{P}_{\beta}:\right.$ FePPIX] & 23 & $"$ \\
\hline $4\left[\mathrm{P}_{\alpha}\right.$ and $\left.\mathrm{P}_{\beta}: \mathrm{MnPPIX}\right]$ & 20 & " \\
\hline $5\left[\mathrm{P}_{\alpha}\right.$ and $\left.\mathrm{P}_{\beta}: \mathrm{FeT} 2 \mathrm{MPyP}\right]$ & 5.1 & " \\
\hline $6\left[\mathrm{P}_{\alpha}\right.$ and $\mathrm{P}_{\beta}:$ MnT2MPyP $]$ & 1.8 & " \\
\hline $7\left[\mathrm{P}_{\alpha}\right.$ and $\left.\mathrm{P}_{\beta}: \mathrm{MnT} 4 \mathrm{MPyP}\right]$ & 2.0 & " \\
\hline \multicolumn{3}{|l|}{ Hemoglobin } \\
\hline $\mathbf{1}\left[\mathrm{P}_{\alpha}=\mathrm{P}_{\beta}=\right.$ FePPIX $]$ & 25 & " \\
\hline FeT4MPyP* & 0.90 & 34 \\
\hline MnT4MPyP & 0.70 & 5 \\
\hline $\mathrm{MnTM}_{3} \mathrm{APP}^{*}$ & 21 & 34 \\
\hline
\end{tabular}

*FeT4MPyP: iron $\{5,10,15,20$-tetrakis(4-N-methylpyridyl)porphyrin $\}$ and $\mathrm{MnTM}_{3} \mathrm{APP}$ : maganese $\{5,10,15,20$-tetrakis(4trimethlaminophenyl)porphyrin.

の系 $\left(\mathrm{IC}_{50}\right.$ で $\left.7>\mathbf{6}\right)$ が, 効果的であり, 低分子系のも の（34）とその傾向は類似であった。しかしながら， カチオン性金属ポルフィリンを含む再構成へモグロビ ン $(5,6$ 打よび 7$)$ の

Inhibition efficiency $=1-\left(\mathrm{v}_{\mathrm{i}} / \mathrm{v}_{\mathrm{o}}\right)$

$\left[\mathrm{v}_{\mathrm{o}}\right.$ and $\mathrm{v}_{\mathrm{i}}$ are formation rates of ferro-cytchrome $\mathrm{c}$ with- out and with the compound having SOD activity, respectively]

$\mathrm{IC}_{50}$ は低分子系のそれに比べ約数倍大きく，やや SOD 活性は低下している。これは, 活性部位周囲に存在す るグロビン鎖の立体障害の影響に基づくと考えられる。

\section{$3 \cdot 2$ 非 XOD 活性阻害性および $\mathrm{O}_{2}^{-\cdots}$ 消去反応性}

再構成へモグロビン活性部位であるカチオン性金属 ポルフィリンの非 XOD 活性阻害性抢よび $\mathrm{O}_{2}{ }^{-}$・消去反 応性について既報（28-30）を参考に検討した。非 $\mathrm{XOD}$ 活性阻害性を $\mathrm{O}_{2}{ }^{-\cdot}$ 生成反応 [(2) 式］において $\mathrm{O}_{2}{ }^{-\cdot}$ と並行して生成する尿酸（キサンチン〜尿酸系） に基づくUV-vis 測定より行った。XOD 添加前では，キ サンチンに基づく吸収ピーク（主に， $\lambda_{\max } 256,263,271$ $\mathrm{nm}$ ）が観測され，XOD を添加するとこれらのピークは 減少し，等吸収点 $(250,278 \mathrm{~nm}$ ) を通って尿酸に基づ く吸収ピーク（主に， $\lambda_{\text {max }} 233,239,290 \mathrm{~nm}$ ）が発現し た。このキサンチン〜尿酸系の変化の最も大きい吸収 ピーク（ $\left.\lambda_{\max } 290 \mathrm{~nm}\right)$ に基づく経時測定を行った (Fig. 5)。XOD 添加後, 尿酸生成に基づく単位時間当 たりの吸光度変化（見かけの生成速度）は一定であり， さらに, 活性部位である MnT2MPyP を添加してもその 単位時間当たりの吸光度変化（見かけの生成速度）は 一定となった。他の系についても同様の結果が得られ た。これより，尿酸は再構成へモグロビン活性部位の 存在の有無によらず一定に生成しており, 再構成へモ グロビンの活性部位による反応阻害はないことが確認 された。

再構成へモグロビンの活性部位が SOD $9 \mathrm{O}_{2}^{-}$-・消去 反応 [(1) 式] と同様な反応で進行していることを $\mathrm{O}_{2}{ }^{-}$- 消去の際に生成される $\mathrm{H}_{2} \mathrm{O}_{2}$ の検出により検討し た。 $\mathrm{H}_{2} \mathrm{O}_{2}$ の検出にはスコポレチン酸化法（スコポレチ ンは $\mathrm{H}_{2} \mathrm{O}_{2}$ 存在下 $\mathrm{HRP} に よ り$ 酸化されて非蛍光物質に 変化するため蛍光が消光する）による蛍光スペクトル 測定より行った。再構成へモグロビンの活性部位 （MnT2MPyP）を添加していない場合，蛍光波長 $460 \mathrm{~nm}$ に基づく蛍光強度の減少は小さかった（減少割 合 5.3\%）が, 活性部位添加の場合では, 蛍光強度は急 激に減少した（減少割合 $88.8 \%$ )。蛍光強度 $\mathrm{H}_{2} \mathrm{O}_{2}$ 濃度 の検量線より $\mathrm{H}_{2} \mathrm{O}_{2}$ 生成は無添加の場合で $0.12 \mathrm{nmol} / \mathrm{ml}$ および添加の場合で $1.57 \mathrm{nmol} / \mathrm{ml}$ となり，添加により $\mathrm{H}_{2} \mathrm{O}_{2}$ 生成が促進されていることが確認された。これよ り, 再構成へモグロビン活性部位は効果的に $\mathrm{O}_{2}{ }^{-\cdot}$ 消去 反応 $[(1)$ 式］を触媒していることが示唆された。

\section{$3 \cdot 3 \mathrm{H}_{2} \mathrm{O}_{2}$ に対する安定性}

$\mathrm{O}_{2}$-・消去反応によって生成された $\mathrm{H}_{2} \mathrm{O}_{2}$ が低分子系の SOD モデル化合物の劣化, 分解等を生じること（触媒 


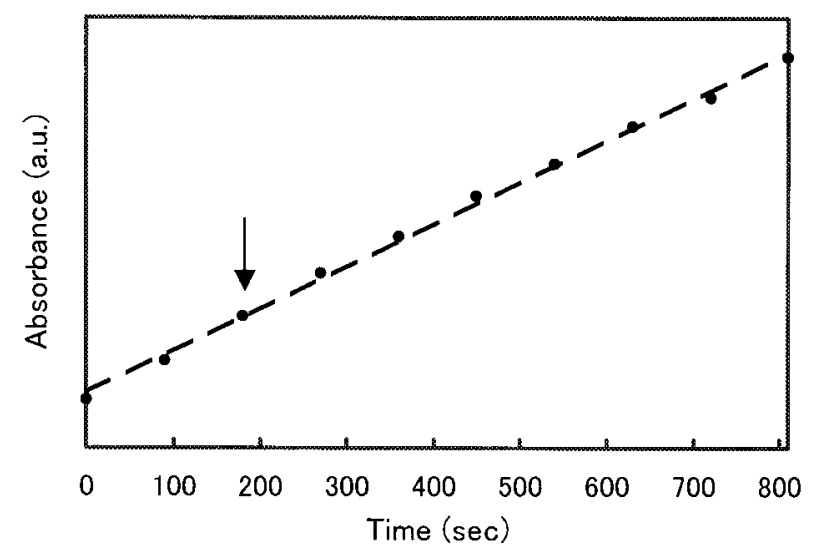

Fig. 5 Absorbance Versus Time Relation at $290 \mathrm{~nm}$ for the Formation of Uric Acid from Xanthine Based on Eq. (1). The arrow in figure indicates the addition of MnT2MPyP.

毒となること）が Pasternack らにより報告されている (3)。そこで, 再構成へモグロビンの $\mathrm{H}_{2} \mathrm{O}_{2}$ に対する安 定性を UV-vis 測定より評価した。参照として低分子系 のカチオン性金属ポルフィリンも同様に評価した。例 えば，MnT2MPyP を含む溶液に $\mathrm{H}_{2} \mathrm{O}_{2}$ を添加して Soret 帯の $\lambda_{\max }$ での経時変化を測定すると急激な吸光度の減 少が見られたが，再構成へモグロビン，6 含む溶液に $\mathrm{H}_{2} \mathrm{O}_{2}$ を添加した場合では緩やかに減少した。この安定 性を定量的に評価するために次のような解析を行った。 これらの劣化，分解等に基づく減衰曲線は一相性の双 曲線であったので，減衰が終了して定常状態となる時 間を SOD モデル化合物の分解・消失時間 $\left(t_{d}\right)$ として 算出し, Fig. 6 にまとめて示す。再構成へモグロビン の $\mathrm{t}_{\mathrm{d}}$ は FeT2MPyP P MnT2MPyP のそれに比べて十数 倍以上となり, 効果的な $\mathrm{H}_{2} \mathrm{O}_{2}$ 耐性を有する。これは, 再構成へモグロビンでは劣化, 分解等の主な機構であ る $\mathrm{H}_{2} \mathrm{O}_{2}$ によるポルフィリン環の開環反応がグロビン鎖 により抑制されているためである。また，予備的では あるが，本再構成へモグロビンの若干のカタラーゼ活 性も部分的に影響しているものと考えられる。

また，一般に，血液中に薬剤を投与した場合，低分 子系のカチオン性化合物では腎臟による尿中排泄，肝 臓への取り込みによるクリアランス等が生じるが，高 分子系ではその影響は少なく，このような点でも低分 子系のカチオン性金属ポルフィリンに比べて本再構成 へモグロビンは優位となる。この評価については，今 後, 検討したい。いづれにせよ, カチオン性金属ポル フィリンを含む再構成へモグロビン $(\mathbf{5} \sim 7)$ は, SOD 活性を示し, $\mathrm{H}_{2} \mathrm{O}_{2}$ 耐性を有する興味深い $\mathrm{SOD}$ モデル 化合物であることが示唆された。

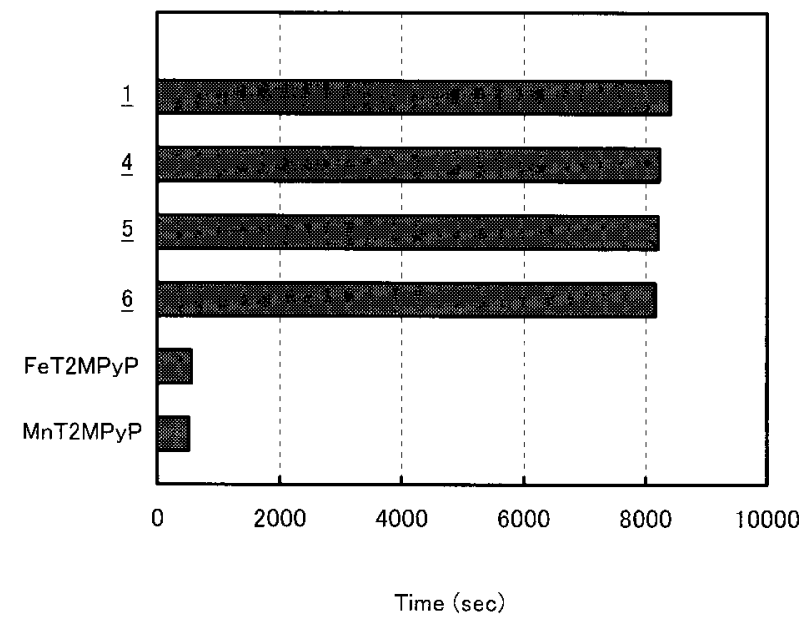

Fig. 6 Disapperance Times $\left(\mathrm{t}_{\mathrm{d}}\right)$ of Reconstituted Hemoglobins and Cationic Metalloporphyrins by $\mathrm{H}_{2} \mathrm{O}_{2}$.

\section{4 結 論}

$\mathrm{O}_{2}{ }^{-・}$ の消去・代謝反応を促進する SOD モデル化合物 の設計指針を得るため, へモグロビンのアポタンパク 質を担体とし，その活性部位を各種金属ポルフィリン 誘導体で置き換えた再構成へモグロビンを合成し，そ れらの SOD 活性を評価したところ，次のような結論が 得られた。

（1）各種の再構成へモグロビンにおいて，サブユ ニットの影響や活性部位の金属イオンの影響を考慮し た再構成へモグロビン $(\mathbf{2} \sim \mathbf{4})$ では良好な SOD 活性 は得られず，カチオン性金属ポルフィリンを含む再構 成へモグロビン $(\mathbf{5} \sim 7)$ で, 興味深いSOD 活性が得 られ，その指標である $\mathrm{IC}_{50}$ は最高で 3.93 である。

（2）再構成へモグロビンの活性部位によるXOD 活性 阻害はなく, さらに, 効果的に $\mathrm{O}_{2}{ }^{-}$消去反応を触媒し ており，SOD と同様に $\mathrm{O}_{2}{ }^{-\cdot}$ を消去するモデル化合物で ある。

（3）再構成へモグロビンの $\mathrm{t}_{\mathrm{d}}$ は低分子系の $\mathrm{Fe}$ T2MPyP や MnT2MPyP のそれに比べて十数倍以上とな り，効果的な $\mathrm{H}_{2} \mathrm{O}_{2}$ 耐性を有する。

（4）（1）〜（3）をまとめると，カチオン性金属ポル フィリンを含む再構成へモグロビン $(\mathbf{5} \sim 7)$ は, SOD 活性を示し, $\mathrm{H}_{2} \mathrm{O}_{2}$ 耐性を有する興味深い SOD モデル 化合物であることが示唆された。

\section{References}

1. M. YUASA, Biomimetic Technologies of Heme Protein Systems, Oleoscience, Vol. 1, 131-137 (2001). 
2. H. KAWAKAMI, Control of Reactive Oxygen Species by Water-soluble Cationic Metalloporphyrin, Oleoscience, Vol. 1, 157-165 (2001).

3. R.F. PASTERNACK and B. HALLIWELL, Superoxide Dismutase Activities of An Iron Porphyrin and Other Iron Complexes, J. Am. Chem. Soc., Vol. 101, 1026-1031 (1979).

4. D. SOLOMON, P. PERETZ and M. FARAGGI, Chemical Properties of Water-soluble Porphyrins. 2. The Reaction of Iron(III) terakis(4- $N$-methylpyridyl)porphyrin with the Superoxide Radical Dioxygen Couple, J. Phys. Chem., Vol. 86, 1842-1849 (1982).

5. K.M. FAULKNER, S.I. LIOCHEV and I. FRIDOVICH, Stable $\mathrm{Mn}(\mathrm{III})$ Porphyrins Mimic Superoxide Dismutase in vitro and Substitute for it in vivo, J. Biol. Chem., Vol. 269, 23471-23476 (1994).

6. D.P. RILEY and R.H. WEISS, Manganese Macrocyclic Ligand Complexes as Mimics of Superoxide Dismutase, J. Am. Chem. Soc., Vol. 116, 387-388 (1994).

7. K. WADA, Y. KOBAYASHI and A. YOKOYAMA, Copper(II) [2, 3butanedione-bi(N-4-methylthiosemicarbazone)], a Stable Superoxide Dismutase-like Copper Complex with High Membrane Penetrability, Arch. Biophys. Biochem., Vol. 310, 1-5 (1994).

8. Z.X. LIU, G.B. ROBINSON and E.M. GREGORY, Preparation and Characterization of Mn-salophen Comlex with Superoxide Scavenging Activity, Arch. Biophys. Biochem., Vol. 315, 74-81 (1994).

9. J.L. PIERRE, P. CHAUTEMPS, S. REFAF, C. BEGUIN, A.E. MARZOUKI, G. SERRATRIE, E. SAINT-AMAN and P. RAY, Imidazolate-bridged Dicopper(II) and Copper-zinc Complexes of a Macrocyclic Ligand (Cryptand). A Possible Model for the Chemistry of $\mathrm{Cu}-\mathrm{Zn}$ Superoxide Dismutase, J. Am. Chem. Soc., Vol. 117, 1965-1973 (1995).

10. H. KAWAKAMI, T. OHSE and S. NAGAOKA, SOD Activity Water-soluble Metalloporphyrins, Porphyeins, Vol. 4, 23-27 (1995).

11. A. DEROCHE, I. MORGENSTERN-BADARAU, M. CESARRIO, J. GUILHEM, B. KEITA, L. NADJO and C. HOUEELEVIN, A Seven Coordinate Manganese(II) Complex Formed with a Single Tripodal Heptadentate Ligand as a New Sueroxide Scavenger, J. Am. Chem. Soc., Vol. 118, 4567-4573 (1996).

12. H. KAWAKAMI, T. NAKAJIMA, T. MORI, S. ASAYAMA, S. NAGAOKA, T. OHIRA, U. MIDOIKAWA and M. YUASA, SOD Activity of Cationic-Porphyrin Having a Cationic Channel, Inter. Symp. Biomater. DDS, Proc., p.176 (2000).

13. K. KALYANASUNDARAM, Photochemistry of Water-soluble Porphyrins: Comparative Study of Isomeric Tetrapyridyl- and Tetrakis(N-methylpyridiniumyl)porphyrins, Inorg. Chem., Vol. 23, 2453-2459 (1984).

14. R.F. PASTENECK, L. FRANCESCONI, D. RAFF and E. SPIRO, Aggregation of Nickel(II), Copper(II), and Zinc(II) Derivatives of Water-soluble Porphyrins, Inorg. Chem., Vol. 12, 2606-2611 (1973).

15. P. HAMBright, T. GORE and M. BURTON, Synthesis and
Characterization of New Isomeric Water-soluble Porphyrins. Tetra(2- $N$-methylpyridyl)porphine and Tetra(3- $N$-methylpyridyl)-porphine, Inorg. Chem., Vol. 15, 2314-2315 (1976).

16. A.D. ADLER, F.R. LONGO, F. KAMPAS and J. KIM, On the Preparation of Metalloporphyrins, J. Inorg. Nucl., Chem., Vol. 32, 2443-2445 (1970).

17. T. YONETANI, H.R. DROTT, J.S. LEIGH, G. REED, M.R. WATERMAN and T. ASAKURA, Electromagnetic Properties of Hemoproteins. 3. Electron Paramagnetic Resonance Characteristics of Iron(II) and Manganese(II) ProtoporphyrinIX and their Apohemoprotein Complexes in High Spin States, J. Biol. Chem., Vol. 245, 2988-3003 (1970).

18. E. BUCCI and C. FRONTICELLI, A New Method for the Preparation of Alpha and Beta Subunits of Human Hemoglobin, J. Biol. Chem., Vol. 240, 551-552 (1965).

19. T. ASAKURA, Studies in Haem-globin Linkage (I). Some Properties of Globin, and Combination of Haem Derivatives and the Globin, Seikagaku, Vol. 36, 35-42 (1965).

20. T. YONETANI and T. ASAKURA, Studies on Cytochrome c Peroxidase. XV. Comparison of Manganese Porphyrin-containing Cytochrome c Peroxidase, Horseradish Peroxidase, and Myoglobin, J. Biol. Chem., Vol. 244, 4580-4588 (1969).

21. M.R. WATERMAN and T. YONETANI, Studies on Modified Hemoglobins. I. Properties of Hybrid Hemoglobins Containing Manganese ProtoporphyrinIX, J. Biol. Chem., Vol. 245, 58475852 (1970).

22. F. ASCOLI, M. ROSARIA, R. FANELLI and E. ANTONINI, Preparation and Properties of Apohemoglobin and Reconstituted Hemoglobin, in Method in Enzymology (E. ANTONINI, L.R. BERNARDI and E. CHIANCONE, eds.), Vol. 91, Academic Press, New York, pp. 72-87 (1981).

23. T. INUBUSHI and T. YONETANI, Synthesis of Modified Porphyrins and Metalloporphyrins, in Method in Enzymology (E. ANTONINI, L.R. BERNARDI and E. CHIANCONE, eds.), Vol. 91, Academic Press, New York, pp. 88-94 (1981).

24. E. BUCCI, Preparation of Isolated Chains of Human Hemoglobin, in Method in Enzymology (E. ANTONINI, L.R. BERNARDI and E. CHIANCONE, eds.), Vol. 91, Academic Press, New York, pp. 97-106 (1981).

25. M. FERRELLA and L. ROSSI-BERNARDI, Detection of Hemoglobin Hybrid Formation at Subzero Temperature, in Method in Enzymology (E. ANTONINI, L.R. BERNARDI and E. CHIANCONE, eds.), Vol. 91, Academic Press, New York, pp. 133-143 (1981).

26. J.M. MCCORD and I. FRIDOVICH, Superoxide Dismutase. An Enzymic Function for Erythrocuprein (Hemocuprein), $J$. Biol. Chem., Vol. 244, 6049-6055 (1969).

27. J. BUTLER, W.H. KOPENOL and E. MARGOLIASH, Kineics and Mechanism of the Reduction of Ferricytochrome $\mathrm{c}$ by the Superoxide Anion, J. Biol. Chem., Vol. 257, 10747-10750 (1982).

28. K. YAGI and M. NAKANO, Active Oxygen, Ishiyaku-shuppan, Tokyo, pp. 86-90 (1987).

29. M.NAKANO, M. ASADA and Y. OYANAGI, Active Oxygen. Molecular Mechanism of its Productions, Scavenging and Effect 
in Organisms, Ishiyaku-shuppan, Tokyo, pp. 32-46 (1988).

30. M. NAKANO, M. ASADA and Y. OYANAGI, Active Oxygen. Molecular Mechanism of its Productions, Scavenging and Effect in Organisms, Ishiyaku-shuppan, Tokyo, pp. 254-261(1988).

31. R.K. ROOT and J.A. METCALF, $\mathrm{H}_{2} \mathrm{O}_{2}$ Release from Human Granulocytes during Phagocytosis. Elationship to Superoxide Anion Formation and Cellular Catabolism of $\mathrm{H}_{2} \mathrm{O}_{2}$ : Studies with Normal and Cytchalasin B-treated Cells, J. Clinc. Invest., Vol. 60, 1266-1279 (1977).

32. L.A. RIO, M.G. ORTEGA and A.L. LOPEZ, A More Sensitive Modification of the Catalase Assay with the Clark Oxygen Elec- trode. Application to the Kinetic Study of the Pea Leat Enzyme, Anal. Biochem., Vol. 80, 409-415 (1977).

33. E.E. DI IORIO, Preparatiob Derivatives of Ferrous and Ferric Hemoglobin, in Method in Enzymology (E. ANTONINI, L.R. BERNARDI and E. CHIANCONE, eds.), Vol. 91, Academic Press, New York, pp. 57-72 (1981).

34. R.H. WEISS, A.G. FLICKINGER, W.J. RIVERS, M.M. HARDY, K.W. ASTON, U. RYAN and D.P. RILEY, Evaluation of Activity of Putative Superoxide Dismutase Mimics. Direct Analysis by Stopped-flow Kinetics, J. Biol. Chem., Vol. 268, 23049-23054 (1993). 